\title{
ANALYSIS OF THE INSTITUTIONAL FRAMEWORK FOR RADIOACTIVE WASTE MANAGEMENT IN INDONESIA
}

\author{
D.S. Wisnubroto* \\ Radioactive Waste Technology Center, BATAN \\ Kawasan Puspiptek Serpong, Tangerang 15310, Banten, Indonesia \\ Received 21 April 2009; Received in revised form 18 August 2009; Accepted 25 August 2009
}

\begin{abstract}
ANALYSIS OF THE INSTITUTIONAL FRAMEWORK FOR RADIOACTIVE WASTE MANAGEMENT IN INDONESIA. The analysis of the infrastructure for radioactive waste management in Indonesia has been studied using several parameters, i.e. policy, regulatory authorities and their regulations, implementing organizations and financial system. By considering the international trends and the Indonesian program to utilize nuclear power, the infrastructure of radioactive waste management needs to be improved. The Act No. 10/1997 on Nuclear Energy for the future beneficence will have to be amended to incorporate several missing key points on waste management, such as definition of radioactive waste, disposal of Low and Intermediate Level Waste (LILW), and classification of waste. Full involvement of some important stakeholders, especially the State Ministry of Environment, on the radioactive waste management infrastructure is required since some radioactive waste is generated from non nuclear waste. Assigning full authority to the State Ministry of Environment for regulating radioactive waste generated by non nuclear facilities may be more effective, whereas BAPETEN is still holding onto control over the waste generated from nuclear facilities. In the near future, several regulations on clearance level, classification of waste, NORM/TENORM, and financial system are expected to be set up for urgent need. By considering the high risk for handling of radioactivity, including for transportation and storage, the liability or assurance of the safety for such activities must be accounted for. Finally, establishment of financial system for long term waste management in Indonesia needs to be implemented to ensure that the radioactive waste will not be the burden on future generations.
\end{abstract}

Keywords : radiactive waste, management, infrastructure, Indonesia, analysis

() 2009 Atom Indonesia. All rights reserved.

\section{INTRODUCTION}

At the present time, Indonesia does not have nuclear power plant (NPP), so that the radioactive waste is mainly coming from the application of radioisotopes in industry, medicine and laboratories. The Radioactive Waste Technology Center (RWTC) under the National Nuclear Energy Agency (BATAN) is the only institution in Indonesia that has capabilities to treat the radioactive waste in the form of liquid, spent resin, combustible waste, high active waste, and sealed sources. RWTC is equipped with evaporator, compactor, incinerator, chemical treatment, conditioning facilities for spent

\footnotetext{
* Corresponding author.

E-mail address: djarot@batan.go.id (D.S. Wisnubroto)
} 
sources and also interim storage. Quite recently the institution has been assigned to manage the interim storage for spent fuels from the research reactors.

Indonesia utilizes radioactive materials and radiation generators for a wide variety of peaceful purposes in industry, medicine, research and education. Many uses involve sealed sources with the radioactive materials firmly contained or bound within a suitable capsule or housing; some also involve radioactive materials in unsealed form. The risks posed by these sources and the materials vary depending on the radionuclide, the form, the activity, etc. Unless breached or leaking, sealed sources present a risk from external radiation exposure only. However, breached or leaking sealed sources, as well as unsealed radioactive materials, may lead to the contamination of the environment and the intake of radioactive materials into the human body.

The general policy of the Government of Indonesia is to return the spent sealed sources to the country of origin. The RWTC has a general principle that sealed sources should not be removed from their holders, or the holders be physically modified (except for Ra-226 needles, smoke detectors and lightning arresters). The RWTC is developing the management information system (MIS) for keeping database of all waste stored in the premises of RWTC. This system is used to identify accurately and immediately the radioactive waste being on the transportation as well as in the storage. The other objective of the MIS is to control the record of the waste history (transportation, treatment/conditioning, and storage).

Although Indonesia has relatively "enough" infrastructure for the present waste comparing to the neighboring countries in South East Asia, it needs improvement especially for the disposal program of the existing waste. Many factors have to be developed in anticipation of the incoming naturally occurring radioactive materials (NORM) waste and technically enhanced naturally occurring radioactive materials (TENORM) waste. Furthermore this improvement of infrastructure is an important factor for preparation of future NPP operation.

There is no standard on the infrastructure of radioactive waste management in the world, however, experience of the nuclear energy countries shows similarities on how to manage the waste to ensure the safety of the public, the workers and the environment. The common infrastructure at least consists of legislation, regulatory authority and implementing organization, but some developing countries may add funding system and clear involvement of the stakeholders [1].

This paper analyzes the infrastructure framework of radioactive waste management in Indonesia by using some parameters as given in Table 1, and the goal is to make every stake holder in Indonesia aware of the necessity to improve the infrastructure of radioactive waste management. 
Table 1. Parameters for analysis.

\begin{tabular}{|l|l|l|}
\hline 1 & Policy/Legislation & $\begin{array}{l}\text { Basic laws, National Structure Organization to } \\
\text { regulate and implement the radioactive waste } \\
\text { management }\end{array}$ \\
\hline 2 & $\begin{array}{l}\text { Regulatory } \\
\text { authorities and their } \\
\text { regulations }\end{array}$ & $\begin{array}{l}\text { Organizations (government agencies) } \\
\text { responsible for regulation of radioactive waste } \\
\text { management, and regulations be published. }\end{array}$ \\
\hline 3 & $\begin{array}{l}\text { Implementing } \\
\text { Organization }\end{array}$ & $\begin{array}{l}\text { Organization (governmental or others) } \\
\text { responsible for implementing radioactive waste } \\
\text { management tasks. }\end{array}$ \\
\hline 4 & $\begin{array}{l}\text { Fund Management } \\
\text { Body }\end{array}$ & $\begin{array}{l}\text { Fund management body/organization } \\
\text { responsible for radioactive waste management } \\
\text { funds. }\end{array}$ \\
\hline
\end{tabular}

\section{ANALYSIS OF THE INFRASTRUCTURE}

Result of the analysis is described below using references from the international trends (from IAEA and other advanced countries), and also evaluation of the common practices in Indonesia (BATAN, waste generator and regulatory body)

\section{Analysis on Policy/Legislation}

In anticipation of possible expansion of the nuclear energy application in Indonesia and in order to contribute to the global nuclear safety culture, in April 1997 the Government of Indonesia, issued the Act of the Republic of Indonesia No. 10/1997 on Nuclear Energy [2]. This law covers various arrangements, including the establishment of Nuclear Energy Regulatory Agency (BAPETEN) by the Presidential Decree No. 76/1998 in May 1998 [3], basic principles of the regulation practices in the application of nuclear energy, basic arrangements for waste management and liability of nuclear damage.

The Act No. 10/1997 on Nuclear Energy consists of 10 chapters with 48 articles. The provision on the waste management consists of 6 articles. With regard to the waste management, the Act clearly stipulates that no part of the Indonesian territory could be used as sites for any foreign or other country radioactive waste repository.

As stated earlier, the Act No. 10/1997 on Nuclear Energy also demands some basic arrangements for waste management. The basic arrangements are accommodated in Chapter VI in 6 articles. Table 2 below shows the articles correlated with the basic policy and the analysis of each article. 
Table 2. Basic policy for radioactive waste management.

\begin{tabular}{|c|c|c|}
\hline Points & Remarks [2] & \multirow{3}{*}{$\begin{array}{l}\text { Analysis } \\
\text { There are radioactive } \\
\text { wastes generated from } \\
\text { non nuclear facilities. } \\
\text { These wastes are not } \\
\text { covered by this } \\
\text { definition. }\end{array}$} \\
\hline Definition & $\begin{array}{l}\text { "any radioactive material and any material } \\
\text { as well as equipment that has been } \\
\text { contaminated by radioactive material or } \\
\text { becomes radioactive due to the operation } \\
\text { of a nuclear installation and cannot further } \\
\text { be used." }\end{array}$ & \\
\hline General safety & $\begin{array}{l}\text { The radioactive waste management shall } \\
\text { be conducted to mitigate radiation hazards } \\
\text { to the workers, the public and the } \\
\text { environment (Article } 22(1) \text { ) }\end{array}$ & \\
\hline $\begin{array}{l}\text { Classification } \\
\text { of radioactive } \\
\text { waste }\end{array}$ & $\begin{array}{l}\text { The radioactive waste is classified into } \\
\text { low, intermediate and high level } \\
\text { radioactive waste (Article } 22(2))\end{array}$ & $\begin{array}{l}\text { Some new } \\
\text { classification has been } \\
\text { established recently. }\end{array}$ \\
\hline $\begin{array}{l}\text { Implementing } \\
\text { Organization }\end{array}$ & $\begin{array}{l}\text { The Executing Body (in this case BATAN) } \\
\text { shall accomplish the radioactive waste } \\
\text { management, for doing which it may } \\
\text { designate a state or private company or } \\
\text { cooperative to conduct commercial waste } \\
\text { management activity (Article 23) }\end{array}$ & \multirow{5}{*}{ 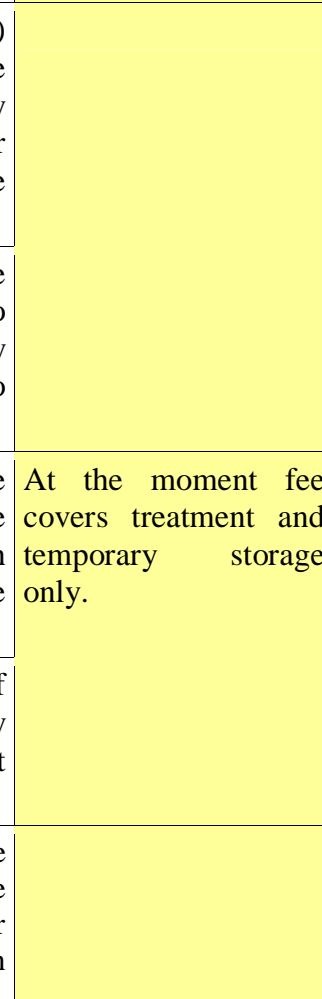 } \\
\hline Operational & $\begin{array}{l}\text { The user generating low and intermediate } \\
\text { level of radioactive waste shall obligate to } \\
\text { collect, segregate, or treat and temporarily } \\
\text { store the waste before being transferred to } \\
\text { the Executing Body (Article } 24(1) \text { ). }\end{array}$ & \\
\hline $\begin{array}{l}\text { Fee for } \\
\text { radioactive } \\
\text { waste } \\
\text { management. }\end{array}$ & $\begin{array}{l}\text { The radioactive waste storage in the } \\
\text { premise of the Executing Body shall be } \\
\text { subjected for fee and the amount of which } \\
\text { will be stipulated in a Decree of The } \\
\text { Minister of Finance (Article 26) }\end{array}$ & \\
\hline $\begin{array}{l}\text { Safety on } \\
\text { Transportation } \\
\text { and Storage }\end{array}$ & $\begin{array}{l}\text { The transportation and storage of } \\
\text { radioactive waste shall consider the safety } \\
\text { of workers, public and environment } \\
\text { (Article } 27(1) \text { ) }\end{array}$ & \\
\hline $\begin{array}{l}\text { Regulations } \\
\text { under the Act. }\end{array}$ & $\begin{array}{l}\text { The provisions on radioactive waste } \\
\text { management including the waste } \\
\text { transportation and disposal shall be further } \\
\text { implemented in Government Regulation } \\
\text { (Article } 27(2))\end{array}$ & \\
\hline $\begin{array}{l}\text { Spent fuel as } \\
\text { high level } \\
\text { waste (HLW) }\end{array}$ & $\begin{array}{l}\text { Nuclear material consists of nuclear ores, } \\
\text { nuclear fuel, and spent fuel. Spent fuel is } \\
\text { considered as HLW (Article } 2 \text { (1) and its } \\
\text { elucidation) }\end{array}$ & $\begin{array}{l}\text { It means Indonesia has } \\
\text { once-through nuclear } \\
\text { fuel cycle policy. }\end{array}$ \\
\hline
\end{tabular}




\begin{tabular}{|l|l|l|}
\hline $\begin{array}{l}\text { Storage period } \\
\text { of spent fuel }\end{array}$ & $\begin{array}{l}\text { The user generating HLW shall be } \\
\text { obligated to temporarily store those wastes } \\
\text { during the period not less than the life time } \\
\text { of the nuclear reactor before being } \\
\text { transferred to the Executing Body (Article } \\
24(2))\end{array}$ & \\
\cline { 1 - 2 } $\begin{array}{l}\text { Disposal for } \\
\text { Low and } \\
\text { Intermediate } \\
\begin{array}{l}\text { Level Waste } \\
\text { (LILW) }\end{array}\end{array}$ & $\begin{array}{l}\text { No article mentions } \\
\text { the disposal for LILW }\end{array}$ \\
\hline $\begin{array}{l}\text { Disposal for } \\
\text { HLW }\end{array}$ & $\begin{array}{l}\text { The Executing Body shall provide the } \\
\text { final repository for high level radioactive } \\
\text { waste (Article 25) }\end{array}$ & \\
\cline { 2 - 3 } $\begin{array}{l}\text { Procedure for } \\
\text { decision of } \\
\text { HLW disposal } \\
\text { site }\end{array}$ & $\begin{array}{l}\text { The siting of final repository under } \\
\text { paragh (1) shall be stipulated by the } \\
\text { from the House of Representatives of the } \\
\text { Republic of Indonesia (Article 25) }\end{array}$ & \\
\hline
\end{tabular}

The above pointers show that Indonesia implements the once-through nuclear fuel cycle policy, so there is no reprocessing need for spent fuel, and spent fuel is defined as high level waste.

While the general safety requirements, classification, implementing organization, fee and disposal of HLW are well explained, there is no article on the disposal for low and intermediate level waste.

As a result, the Government finds difficulties to regulate the disposal of low and intermediate level waste. Although the Government Regulation No. 27/2002 on the safety of radioactive waste management can overcome this problem by using the term "Storage" ("Penyimpanan" in Indonesian language) for the repository/disposal activity, and "Temporary Storage" ("Penyimpanan Sementara" in Indonesian language) for its real meaning [4], in the long term it will be difficult for the public to comprehend. The only solution is to amend this act, although it takes time to process this action.

The other problems that may occur in the future is the need to classify the naturally occurring radioactive materials (NORM) and the technically enhanced naturally occurring radioactive materials (TENORM). This is because NORM and TENORM are not generated from nuclear facilities, rather from the common industries, while the definition of radioactive waste in the Act No. 10/1997 is "any radioactive material and any material as well as equipment that has been contaminated by radioactive material or becomes radioactive due to the operation of a nuclear installation and cannot further be used". So at present in Indonesian law the radioactive waste is only generated 
by nuclear facilities. So the NORM/TENORM waste is in the position undefined waste under the nuclear law.

Although every country has its own classification, the Indonesian Regulation only recognizes 3 classes (high, intermediate and low level), and this may cause complication in the future since in reality there are other wastes such as exempt waste, long-lived waste, short-lived waste, and very low level waste, and that each has special treatment and disposal method.

\section{Analysis on National Organization}

The Act No. 10 of 1997 states that the development and the use of nuclear energy has to be carried out in such a way to assure the safety and health of workers, as well as the public and also to protect the environment.

To carry out the development and the use of nuclear energy, the Government has established the National Nuclear Energy Agency (BATAN) as the Executing Body, the Nuclear Energy Regulatory Agency (BAPETEN) as the Regulatory Body and in the future the Nuclear Energy Advisory Council will be established, all of these three bodies are being under management of and directly responsible to the President of the Republic of Indonesia.

The Executing Body has the task to execute the use of nuclear energy by conducting research and development, general surveys, exploration and exploitation of radioactive minerals and nuclear fuel cycle, production of radioisotopes and radioactive substances for research and development, and radioactive waste management. While BATAN as the executing body performs the non-commercial activities, the commercial ones can be done in cooperation with and or by private companies, state-owned enterprises and cooperatives.

The Regulatory Body as the independent organization has the task to control any activity using nuclear energy. The purpose of control is to prevent the workers, the public, and the environment from any harmful effect of radiation.

The task is administered by the following means:

- Establishing regulation on the nuclear safety.

- Issuing the licenses to control that the user of nuclear energy is qualified and in accord with the nuclear safety regulation, criteria, standards, and guidance as well as practices.

- Doing inspection to ensure that all regulations are observed in practices.

According to the Act, the Nuclear Energy Advisory Council has to be established, and this body has the functions to give advice and opinions on the use of nuclear energy to the President of the Republic of Indonesia. The Nuclear Energy Advisory Council is an independent and a non-structural 
institution, and its members consist of experts and public figures. This Council still in the process to be established.

The structure of the radioactive waste management in Indonesia is illustrated in Figure 1. The structure shows that BATAN, BAPETEN and the Ministry of Research and Technology respectively set up the plans and coordinate research and development activities.

On the regulatory side, the Nuclear Energy Regulatory Agency coordinates the regulation, guidance and criteria as well as examines the safety assessment. The Nuclear Energy Regulatory Agency carries out the safety examination on the waste management organization to comply with the basic radiation protection requirements as described in ICRP and IAEA Basic Safety Standard. The Radioactive Waste Technology Center (RWTC), BATAN is the undertaking organization, as well as the responsible party for carrying out the radioactive waste management which is the statutory task of the Executing Body.

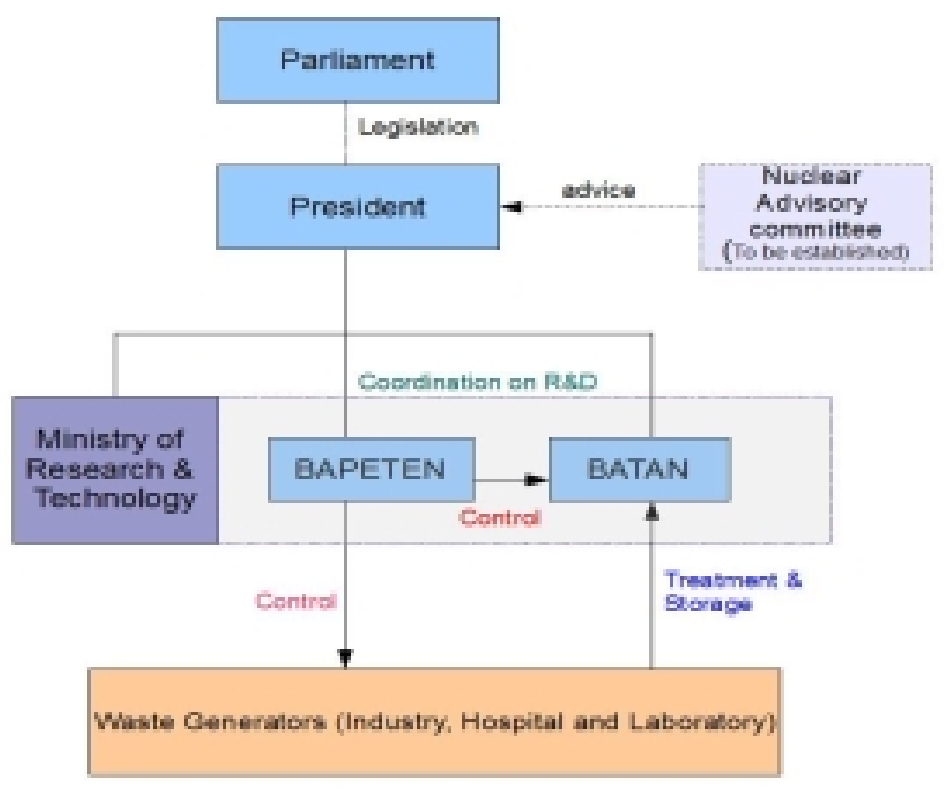

Figure 1. Radioactive waste management structure in Indonesia. 
The structure above shows a very simple organization flowchart in Indonesia, which needs to be improved by considering the followings:

- The position of the State Ministry of Environment in the radioactive waste management, since radioactive waste management has a strong impact on the environment, especially on the disposal of radioactive waste.

- The NORM/TENORM generation in the non nuclear industries will to be a serious problem, and usually the NORM waste has huge volume, that can not be dealt with only by the above structure, as involvement of other ministries such as the Ministry of Energy and Mineral Resources, the Ministry of Health, and also the State Ministry of Environment can not be avoided. In addition, there are many cases where NORM and common hazardous waste are mixed, so these parties must collaborate to solve the mixed waste problem.

- Funding or financial system that has to be developed to avoid the burden on future generations. So the present generation must collect the fund to ensure that disposal of waste is safe for long period. Some countries use government organization (such as ministry of finance), or independent organization or other method for collecting the fun [1].

- It is more effective to split the regulatory function on radioactive waste into two: BAPETEN for the waste from nuclear facilities, and the State Ministry of Environment for waste from non nuclear facilities since this ministry has a strong authority on non nuclear industries.

The Act No. 10 of 1997 states that the development and the use of nuclear energy has to be carried-out in such a way to assure the safety and health of workers, as well as the public and also to protect the environment.

\section{Analysis on Regulatory}

The regulation is prepared to regulate and control the nuclear activities by the regulatory body in compliance with the basic radiation protection requirements as described in ICRP and IAEA Basic Safety Standard and other applicable requirements, the early planning stage of a project in the form of environmental impact analysis preparation, licensing application, regulating and controlling of activities. Certain necessary rules and regulations for the management of radioactive waste have been issued as indicated in Table 3. 
Table 3. List of existing Indonesian Government Regulations concerning. radioactive waste management.

\begin{tabular}{|c|c|}
\hline No. & \\
\hline 1. & Government Regulation No. 27/2002 on Radioactive Waste Management \\
\hline 2. & $\begin{array}{l}\text { Government Regulation No. 26/2002 on the Safety of Transportation of } \\
\text { Radioactive Materials. }\end{array}$ \\
\hline 3. & vernment Regulation No. 43/2007 on Operation of Nuclear Reactors \\
\hline 4. & Government Regulation No. 77/2008 on Waste Management Fee \\
\hline 5. & $\begin{array}{l}\text { Government Regulation No. 63/2000 on Working Safety Against } \\
\text { Radiation }\end{array}$ \\
\hline 6. & $\begin{array}{l}\text { Government Regulation No. } 64 / 2000 \text { on Licensing of Utilization of } \\
\text { Radioactive Materials and or Other Radiation Sources }\end{array}$ \\
\hline 7. & $\begin{array}{l}\text { ment Regulation No. 51/1993 on the Preparation of Environment } \\
\text { Analysis }\end{array}$ \\
\hline 8. & $\begin{array}{l}\text { Decree of the Minister of Environment No. Kep.-42/MENLH/1994 on } \\
\text { General Guidelines on Environmental Audit }\end{array}$ \\
\hline 9. & $\begin{array}{l}\text { Decree of the Minister of Environment No. Kep.-39/MENLH/1996 on } \\
\text { Criteria of Activities Requiring an Environment Impact Analysis }\end{array}$ \\
\hline 10. & Indonesia No. 10/1997 on Nuclear Energy \\
\hline 11. & $\begin{array}{l}\text { Act of the Republic of Indonesia No. 23/1997 on Environment } \\
\text { Management }\end{array}$ \\
\hline 12. & $\begin{array}{l}\text { Decree of the President of the Republic of Indonesia No. } 76 / 1998 \text { on } \\
\text { Nuclear Energy Regulatory Agency }\end{array}$ \\
\hline 13. & $\begin{array}{l}\text { Decree of the Chairman of the Nuclear Energy Regulatory Agency No. } \\
\text { 01/Ka. BAPETEN/V-99 on Provisions for Occupational Safety Against } \\
\text { Radiation }\end{array}$ \\
\hline 14. & $\begin{array}{l}\text { the Chairman of the Nuclear Energy Regulatory Agency No. } \\
\text { PETEN/V-99 on Radioactivity Dose Value for the Environment }\end{array}$ \\
\hline 15. & $\begin{array}{l}\text { ar Energy Regulatory Agency No. } \\
\text { ect of Radioactive Waste }\end{array}$ \\
\hline 16. & $\begin{array}{l}\text { Decree of the Chairman of the Nuclear Energy Regulatory Agency No. } \\
\text { 04/Ka. BAPETEN/V-99 on Radioactive Materials Transport Safety }\end{array}$ \\
\hline 17. & $\begin{array}{l}\text { Decree of the Chairman of the Nuclear Energy Regulatory Agency No. } \\
\text { 06/Ka. BAPETEN/V-99 on Construction and Operation of Nuclear } \\
\text { Reactor }\end{array}$ \\
\hline 18. & r Energy Regulatory Agency No. \\
\hline
\end{tabular}

Many significant issues on radioactive waste management are still not covered in the above regulations, such as:

- Clearance level. This level is of great importance to determine whether the waste still can be classified as radioactive or not. Some of the wastes that are stored in BATAN may not be radioactive anymore. Or more significantly is, by the value of clearance level there will be effort of every waste generator and operator to manage and treat the waste so the product 
can reach the value under the clearance level. The clearance level is also important in the decommissioning program of nuclear facilities, it will affect the amount of waste generated and also the fund required for that program.

- Regulation on NORM/TENORM. It seems that a joint work between the BAPETEN and the State Ministry of Environment to establish the NORM/TENORM regulation is preferable, and it is expected to be more effective since the Ministry of Environment is the only institution in Indonesia that has the authority on the environment control and capability to stop any activity of non nuclear industries that violate the law/regulation. Although recently BAPETEN has souhgt to establish the TENORM regulation, but without proper authority it may not be effective to control the non nuclear industries.

- Regulation on fund/financial system. As described above the regulation is essential. At present, the government has a regulation on the waste management fee [5]. It means that every waste generator must pay the government a fee for waste management service in BATAN. However the tariff that has been established is excluding the disposal parameter. If the disposal parameter is included, then the cost will be expensive for waste generators to pay, and it is predicted in many cases that the fee for waste management will be higher than that for new radiation source. However for the near future program, especially for preparation of NPP operation, regulation on funding is necessary, not only to establish the fee or tariff but also the organization that manages the fund.

- As mentioned above, that Act. no. 10/1997 does not mention the disposal of low and intermediate level waste. The only way to address the problem is to amend the Act, so it will provide a clear policy on the repository.

- Regulation on waste classification. The Act No. 10/1997 is not appropriate anymore to describe the classification of waste. The government regulation under the Act can not accomodate new definitions, such as very low level waste, or long-lived waste, or shortlived waste since these terms are not in the Act.

\section{Analysis on The Responsibility of License Holder}

Radioactive waste management shall be administered by the Executing Body based on the safety concern and technical capability possessed by the Executing Body and also for the ease in implementation of control. The management is administered in a non-commercial manner. For commercial activities of radioactive waste management, the Executing Body may designate a state-owned company, cooperatives, and/or any private company in accordance with the existing regulations.

The obligation of the user generating low and medium level radioactive waste is to manage the radioactive waste within the location of 
the nuclear installation so that they will not pose hazards to the workers, the public and the environment, enabling further easy management by the Executing Body. The purpose of temporary disposal is to reduce the radiation level of short-lived radioactive materials before transferring them to the Executing Body. The user generating high level radioactive waste shall be obligated to temporarily store the wastes (spent fuel) during the period not less than the life time of the nuclear reactor.

The determination of a final repository site for high level radioactive waste shall be discussed with the House of Representatives of the Republic of Indonesia to obtain approval, since it converts the function of a beneficial site to a site that can never be used for anything else. Radioactive waste from other countries shall not be allowed to be disposed of in the territory of the Republic of Indonesia.

Further, the Act No. 10/1997 on Nuclear Energy [2] also stipulates some basic arrangement of nuclear damage liability related to responsibility of license holder. The basic arrangements accommodated in Chapter VII are as follows:

- The Operator of a nuclear installation shall be liable for damage suffered by the third party resulting from any nuclear incident inside the nuclear installation (Article 28)

- In the case of nuclear damage occurring during the transportation of nuclear fuel or spent fuel, the Consignor shall be liable for nuclear damage suffered by the third party (Article 29 (1))

- The Consignor under paragraph (1) may transfer the liability to the Consignee or the Carrier, by written agreement (Article 29 (2))

- Where nuclear damage engages the liability, under Article 28, of more than one Operator, the Operators involved shall, in so far as the damage attributable to each Operator is not reasonably separable, be jointly and severally liable (Article 30 (1))

- The liability of each Operator under paragraph (1) shall not exceed each liability limit in respect to any one of them (Article 30 (2))

- If a nuclear incident has occurred in one location having more than one nuclear installation under one Operator, the Operator shall be liable for damage in any individual installation (Article 31)

- The Operator shall not be liable for damage caused by a nuclear incident directly due to an act of international or non-international armed conflict, or a grave natural disaster exceeding the safety limit established by the Regulatory Body (Article 32)

- If the Operator having paid the compensation under Article 28 is able to prove that the nuclear damage resulted from the intent of the third party suffering the damage the Operator may be relieved wholly or partly from his obligation to pay compensation (Article 33 (1)) 
- The Operator under paragraph (1) shall have a right of recourse against the third party who has acted with intent causing nuclear damage (Article 33 (2))

The case of liability needs to be elucidated more as the liability articles above are entirely for fissile materials and nuclear facilities, they are and not appropriate for most of the radioactive waste management except for the spent nuclear fuel. By considering Indonesia as an archipelago country with poor transportation infrastructure, the transportation of radioactive materials is one of the most unsafe and insecure activity. Although it is stated in the Government Regulation No. 26/2002 [6] that the Consignor (in the case of waste management is the waste generator) is responsible for the transportation of radioactive material, there is, however, no statement further about the liability or even assurance. In the future, this kind of assurance for radioactive materials must be considered not only in the transportation but also in the security of the storage of radioactive materials, since there have been numerous cases involving the loss or stealing of radioactive sources [7]. Therefore, liability involving the radioactive material/waste is as important as nuclear liability.

\section{Analysis on Financial System}

Since many of the activities associated with long term waste management of waste will take place several decades (or more) into the future (possibly after the generators of the waste have gone out of business), it is prudent to collect the financial resources that will be needed for future operations while the waste generators are still in operation. Many countries indicated that they use various financial systems to ensure the long term availability of financial resources for their geological disposal programs. Funds and reserves are the two most common financial systems. In the former, the financial resources are usually maintained by organizations independent from the waste generators. In the Russian Federation, financing is obtained from the national budget [1]. The scope of financial system differs from country to country (e.g. some include such activities as decommissioning of nuclear facilities, and management of low level waste, while others are intended only for HLW or spent nuclear fuel). Accordingly the activities covered by the funds vary from country to country, as follows [1]:

- Only HLW and/or SNF disposal (Czech Republic, Japan, USA)

- Interim storage and disposal of SNF (Belgium, Finland)

- Decommissioning of nuclear power plants, as well as storage and disposal of HLW and/or SNF (Hungary, Lithuania, Spain, Sweden, Switzerland). 
The annual fees that are widely used to obtain the resources kept in the funds are generally calculated and determined based on the amount of electricity or waste generated in a certain year (i.e. on the basis of the future liability associated with the waste generated in that year). Table 3 below shows the waste management fees for several countries.

Table 3. Waste management fees [1].

\begin{tabular}{|c|c|c|}
\hline Country & Fee per KWh & Remarks \\
\hline USA & US $\$ 0.001$ & HLW/Spent fuel disposal \\
\hline Japan & $¥ 0.13$ & HLW/Spent fuel disposal \\
\hline Finland & $€ 0.0023$ & Spent fuel storage and disposal \\
\hline Spain & $\begin{array}{c}0.8 \% \text { of the retail price of } \\
\text { electricity generated by all } \\
\text { power stations }\end{array}$ & $\begin{array}{c}\text { Including decommissioning, } \\
\text { storage and disposal spent fuel } \\
\text { and other wastes. }\end{array}$ \\
\hline
\end{tabular}

At the moment Indonesia does not have financial system for radioactive waste management, normally only countries with NPPs have such system. However, sooner or later the NPP program in Indonesia must be supported by the financial system that includes fund organization (may be independent or governmental organization) and fees (for decommissioning, storage and disposal of spent fuel and other waste). At present, the government has a regulation on the waste management fee [5]. It means that every waste generator must pay the government a fee for waste management service in BATAN. However the tariff that has been established is only based on the treatment and temporary storage, as explained above. Depending on the development of nuclear energy, arrangement of financial system in Indonesia must be established to ensure that the radioactive waste will not be the burden on future generation.

\section{CONCLUSION}

Although Indonesia has better infrastructure of radioactive waste management for the existing waste comparing to other countries in the region, however, by considering recent trends in the international community to enhance the safety of radioactive waste management, and also by considering the Indonesian program to utilize nuclear power, the infrastructure needs to be improved i.e. on the legislation, national organizations, regulations, liabilities and financial system. The Act no. 10/1997 on Nuclear Energy, for the future beneficence, will have to be amended incorporate several missing key points on waste management such as definition of radioactive waste, disposal of LILW, and classification of waste. Involvement of some important stakeholders especially the State Ministry of Environment on the radioactive waste management infrastructure is required since some radioactive waste is generated from non nuclear waste. 
Assigning full authority to the State Ministry of Environment for regulating radioactive waste generated by non nuclear facilities may be more effective, whereas BAPETEN is still holding on to control over the waste generated from nuclear facilities.

In the near future several regulations on clearance level, classification of waste, NORM/TENORM, and financial system are expected to be set up for urgent need. By considering the high risk for handling of radioactivity including for transportation and storage, the liability or assurance of the safety for such activities must be considered. Finally, establishment of financial system for long term waste management in Indonesia needs to be implemented to ensure that the radioactive waste will not be the burden on future generation.

\section{REFERENCES}

1. IAEA, "Institutional Framework for Long Term Management of High Level or Spent Nuclear Fuel”, IAEA-TECDOC-1323, Vienna (2002).

2. THE REPUBLIC OF INDONESIA, Act of the Republic of Indonesia No. 10/1997 on Nuclear Energy (2007).

3. THE REPUBLIC OF INDONESIA, Presidential Decree No. 76/1998 on Establishment of Regulatory Body (1998).

4. THE REPUBLIC OF INDONESIA, Government Regulation No. 27/2002 on Radioactive Waste Management (2002).

5. THE REPUBLIC OF INDONESIA, Government Regulation No. 77/2008 on Waste Management Fee (2008).

6. THE REPUBLIC OF INDONESIA, Government Regulation No. 26/2002 on the Safety of Transportation of Radioactive Materials (2002).

7. BAPETEN, “Nuclear Safety Report 2007”, BAPETEN, Jakarta (2007). 